\title{
An Analysis of Laboratory Characteristics of Patients with Suspected Rheumatoid Arthritis
}

\author{
Romatoid Artrit Şüphesi Olan Hastaların Laboratuvar Özelliklerinin Analizi
}

\author{
İhsan Hakkı ÇİFTCİ, ${ }^{1}$ Gülşah AŞIK, ${ }^{2}$ Hasan TOKTAŞ, ${ }^{3}$ Davut ÇUFALI, ${ }^{2}$ Ümit DÜNDAR, ${ }^{3}$ Engin KARAKEÇE ${ }^{1}$ \\ ${ }^{1}$ Department of Microbiology, Medical Faculty of Sakarya University, Sakarya, Turkey \\ ${ }^{2}$ Department of Microbiology, Medical Faculty of Kocatepe University, Afyonkarahisar, Turkey \\ ${ }^{3}$ Department of Physical Medicine and Rehabilitation, Medical Faculty of Kocatepe University, Afyonkarahisar, Turkey
}

\begin{abstract}
Objectives: The aim of this study was to characterize a population of patients with rheumatological signs and symptoms according to laboratory tests.
\end{abstract}

Patients and methods: Data of a total of 386 patients (90 males, 296 females; mean age 45.9 years; range 14 to 91 ) with rheumatological signs and symptoms for a three-year period were retrospectively analyzed. Inflammatory activity using erythrocyte sedimentation rate (ESR) and C-reactive protein (CRP) tests were evaluated at the microbiology laboratory of Afyon Kocatepe University, Faculty of Medicine, Afyonkarahisar. The presence of rheumatoid factor (RF) and cyclic citrullinated peptide (CCP) antibodies were also analyzed. The ESR $(\mathrm{mm} / \mathrm{h})$ was determined by standard methods, while the RF and CRP were measured by immunonephelometry. The anti-CCP was studied by using a test kit according to the manufacturer's instructions.

Results: A total of 270 patients were examined in a physical medicine and rehabilitation clinic. The results for anti-CCP, RF, CRP, and ESR were positive in 58 (21.5\%), 77 (28.9\%), $120(44.4 \%)$ and 107 patients (39.6\%) respectively. Among these patients, a total of 67 were diagnosed with rheumatoid arthritis (RA). When we considered the association of ESR, $\mathrm{CRP}, \mathrm{RF}$, and anti-CCP positivity with RA diagnosis, both anti-CCP $(\Phi=0.920)$ and RF $(\Phi=0.782)$ had a high positive correlation with RA. There was a close association between CRP $(\Phi=0.289)$ and ESR $(\Phi=0.236)$. Each of them had a moderate correlation with RA.

Conclusion: Our study results showed that anti-CCP, followed by RF was the most closely associated autoantibody in suspected RA patients. The anti-CCP and RF combination provided the best test sensitivity.

Key words: Anti-cyclic citrullinated peptide; laboratory findings; suspected rheumatoid arthritis.
Amaç: Bu çalışmada laboratuvar testleri ile romatolojik bulgu ve belirtileri olan bir hasta nüfusu tanımlandı.

Hastalar ve yöntemler: Toplam 386 hastanın (90 erkek, 296 kadın, ort. yaş 45.9; dağılım 14-91 yıl) üç yıllık bir döneme ait romatolojik bulgu ve belirtilerine ilişkin veriler, retrospektif olarak incelendi. Inflamatuvar aktivite eritrosit sedimentasyon hızı (ESR) ve C-reaktif protein (CRP) testleri kullanılarak, Afyon Kocatepe Üniversitesi Tıp Fakültesi mikrobiyoloji laboratuvarında değerlendirildi. Romatoid faktör (RF) ve siklik sitrüline peptid (CCP) antikorları da analiz edildi. Eritrosit sedimentasyon hızı (mm/sa) standart yöntemler ile tayin edilirken, RF ve CRP immünonefelometri ile ölçüldü. Anti-CCP, üretici firmanın talimatları doğrultusunda bir test kiti ile çalışıldı.

Bulgular: Toplam 270 hasta fizik tedavi ve rehabilitasyon kliniğinde muayene edildi. Anti-CCP, RF, CRP ve ESR sonuçları sırasıyla 58 (\%21.5), 77 (\%28.9), 120 (\%44.4) ve 107 hastada (\%39.6) pozitif idi. Bu hastalar arasında toplam 67 kişiye romatoid artrit (RA) tanısı kondu. Romatoid artrit tanısında ESR, CRP, RF ve anti-CCP pozitifliği göz önünde bulundurulduğunda, en yüksek düzeyde anti-CCP $(\Phi=0.920)$ ve $\operatorname{RF}(\Phi=0.782)$ RA ile pozitif ilişkilendirildi. Ayrıca, CRP $(\Phi=0.289)$ ve ESR $(\Phi=0.236)$ arasında da yakın bir ilişki vardı. Her biri RA ile orta düzeyde ilişkiliydi.

Sonuç: Çalışma bulguları, anti-CCP'nin ve takiben RF'nin RA şüphesi olan hastalarda otoantikor ile en yakın ilişkili olduğunu gösterdi. Anti-CCP ve RF kombinasyonu, en iyi test duyarlılığını verdi.

Anahtar sözcükler: Anti-siklik sitrüline peptid; laboratuvar bulguları; şüpheli romatoid artrit. 
Autoimmunity is the basic feature of rheumatoid arthritis (RA), which has high plasma autoantibody titers. $^{[1]}$ After the progression of the rheumatic autoimmune disease, it causes systemic symptoms with bone and cartilage damage due to synovial tissue inflammation. There are hundreds of different types of arthritis, but RA causes more joint damage than the others. Therefore, diagnosing RA and developing a treatment plan before any damage occurs is crucial, ${ }^{[2]}$ and the diagnosis is made by the clinician after examining a patient's medical history, clinical examination, and laboratory and imaging results.

Most chronic diseases have a gold standard for evaluation methods, but RA has none, which causes difficulty in the diagnosis. In the 1940s, the rheumatoid factor (RF) was discovered, but it could not meet the expectations for the diagnosis of RA due to its lack of sensitivity and specificity. In more recent years, high specificity and sensitivity rates caused by autoantibodies that target citrullinated epitopes have been utilized for the diagnosis of RA. As a result, in 2010, the anti-cyclic citrullinated peptide (anti-CCPs) was included in the American College of Rheumatology (ACR)/European League Against Rheumatism (EULAR) RA classification criteria. ${ }^{[3,4]}$

This study was conducted for the purpose of determining the relationship between RA and the erythrocyte sedimentation rate (ESR) and C-reactive protein (CRP) as well as the correlation between RF and anti-CCP autoantibody positivity which can be used as indicators of inflammation for patients with rheumatic complaints.

\section{PATIENTS AND METHODS}

In the study, the data of 386 patients (90 males, 296 females; mean age 45.9 years; range 14 to 91 ) who were referred to our hospital clinics with rheumatic complaints and findings between January 2008 and December 2010 was evaluated retrospectively. Both ESR and CRP were accepted as criteria for the evaluation of inflammatory activity, and their threshold values are given in Table 1. By employing the same immunonephelometry method commonly used for evaluating ESR, the data regarding RF and CRP was also derived. In addition, anti-CCP measurements were calculated using the Quanta Lite ${ }^{\oplus}$ CCP IgG ELISA test kit (Inova Diagnostics Inc., San Diego, California, USA) in accordance with the manufacturer's protocol. The value limits for all of the laboratory studies are also presented in Table 1.

The anti-CCP tests for $69.9 \%$ of the patients $(n=270)$ were conducted at the physical medicine and rehabilitation (PMR) clinics while the tests for the other $30.1 \% \quad(n=116)$ were done at other clinics. Patients were excluded from the study if a prediagnosis of RA was not presumed by the PMR clinic or if at least one test result was absent that was to be used for diagnostic purposes. A diagnosis of RA was determined by the PMR clinic in accordance with the 1987 ACR criteria until September 2010 and the 2010 ACR/EULAR criteria after September 2010. All patient data was evaluated using the Statistical Package for the Social Sciences (SPSS Inc., Chicago, Illinois, USA) version 17.0 for Windows software program. The relationship between the RA diagnosis and laboratory data was investigated by analyzing the phi correlation coefficient.

\section{RESULTS}

During the study period, it was noted that ESR, CRP, $\mathrm{RF}$, and anti-CCP tests had been requested for the 386 patients who had been referred to the various clinics with rheumatic complaints, and 270 of these had been prediagnosed with RA and been directed to the laboratory by the PMR department. The clinical and laboratory findings revealed that $24.7 \%$ of the patients $(n=67)$ who had been prediagnosed by the PMR clinic with RA actually had this disease, and $44 \%$ of the total patients tested positive for CRP $(n=120), 39.6 \%$ for ESR ( $n=107), 28.9 \%$ for RF ( $n=77)$, and $21.5 \%$ for

Table 1. Results of laboratory tests used in the diagnosis of rheumatoid arthritis

\begin{tabular}{|c|c|c|c|c|c|c|}
\hline \multirow[t]{2}{*}{ Test } & \multirow[t]{2}{*}{ Threshold* } & \multicolumn{2}{|c|}{ Positive } & \multicolumn{2}{|c|}{ Negative } & \multirow[b]{2}{*}{$\Phi^{* *}$} \\
\hline & & $\mathrm{n}$ & $\%$ & $\mathrm{n}$ & $\%$ & \\
\hline Anti-cyclic citrullinated peptide antibody & $25 \mathrm{U} / \mathrm{ml}$ & 58 & 21.5 & 212 & 78.5 & 0.920 \\
\hline Rheumatoid factor & $20 \mathrm{U} / \mathrm{ml}$ & 77 & 28.9 & 193 & 71.1 & 0.782 \\
\hline C-reactive protein & $0.08 \mathrm{~g} / \mathrm{dl}$ & 120 & 44.4 & 150 & 56.6 & 0.289 \\
\hline \multirow{2}{*}{ Erythrocyte sedimentation rate } & Male $15 \mathrm{~mm} / \mathrm{s}$ & & & & & \\
\hline & Female $20 \mathrm{~mm} / \mathrm{s}$ & 109 & 39.6 & 161 & 60.4 & 0.236 \\
\hline
\end{tabular}




\begin{tabular}{|c|c|c|c|c|c|}
\hline Test & Sensitivity & Specificity & $\begin{array}{c}\text { Positive } \\
\text { predictivity }\end{array}$ & $\begin{array}{c}\text { Negative } \\
\text { predictivity }\end{array}$ & $\begin{array}{c}\text { Accuracy } \\
\text { rate }\end{array}$ \\
\hline Anti-cyclic citrullinated peptide antibody & 0.8657 & 1.0000 & 1.0000 & 0.9575 & 0.9667 \\
\hline Rheumatoid factor & 0.8955 & 0.9113 & 0.7692 & 0.9635 & 0.9076 \\
\hline C-reactive protein & 0.7164 & 0.6453 & 0.4000 & 0.8733 & 0.6630 \\
\hline Erythrocyte sedimentation rate & 0.5970 & 0.6700 & 0.3738 & 0.8344 & 0.6519 \\
\hline
\end{tabular}

anti-CCP $(\mathrm{n}=58)$. All of these percentages were above the normal values. Statistical analysis determined that anti-CCP had the highest correlation percentage with the RA diagnosis $(\Phi=0.920, p=0.000)$ among all of the laboratory tests. This was followed by $\mathrm{RF}(\Phi=0.782$, $\mathrm{p}=0.000$ ). Other data obtained from the study is summarized in Table 1.

According to the calculations based on RA diagnosis, it was observed that anti-CCP also had the highest specificity when considering all of the tests studied in this context. The values of anti-CCP were as follows: sensitivity $=0.8657$, specificit $y=1.0$, positive predictivity $=1.0$, negative predictivity $=0.9575$, and accuracy $=0.9667$. Calculations for the other test data is summarized in Table 2.

\section{DISCUSSION}

Rheumatoid arthritis is a chronic inflammatory rheumatic disease which has a complex heterogeneous phenotype and genotype. ${ }^{[5]}$ Due to the heterogeneity of the disease, during the diagnosis, the medical history of the patient along with the opinion of the clinician is very important, as is the case with other rheumatic diseases. To reduce false diagnoses and to follow-up the patients in a uniform manner, some classification and diagnostic criteria were developed. Laboratory tests, which are considered to be more objective, were later added to these criteria lists along with pain and joint swelling and radiological findings based on the clinician's interpretation. Rheumatoid factor was first mentioned in 1958 in the Association of American Rheumatism (ARA) evaluation criteria. Anti-CCP and $\mathrm{RF}$ were added to the ACR/EULAR classification criteria in 2010. The anti-CCP is a test used to measure the level of autoantibodies that are growing against CCP structures. ${ }^{[4,6]}$

Acute phase response develops through RA due to tissue damage that forms in connection with inflammation and as the result of metabolic stress exposure of the cells. The most common test uses ESR for the purpose of indirectly measuring the acute phase response. ${ }^{[7]}$ However, the ESR was not to be evaluated as the only decisive test for disease diagnosis, and it was not to be considered in the diagnostic or classification criteria. The ESR has a low sensitivity and specificity for RA diagnosis; however, although it is elevated in many diseases, it may not be elevated in some patients diagnosed with RA. It only remains among the ACR criteria when considering remission. ${ }^{[8]}$ An ESR rate of 55\% was reported for patients who had been diagnosed with RA in a multicenter study conducted in Finland and the United States, ${ }^{[6]}$ and this rate was above the threshold value. In our study, among the patients who were referred to clinics with rheumatic complaints, only $39.6 \%$ had high ESR values. Additionally, we calculated that there was a low level of positive correlation between RA diagnosis and ESR $(\Phi=0.236)$. Our results were not in harmony with the data in the literature since only $50 \%$ of our RA patients had elevated ESR. Our hospital, being a third-level health organization, accepts patients from neighboring hospitals. Furthermore, our PMR rheumatic diseases clinic accepts patients to verify a prediagnosis of RA and to perform anti-CCP testing on them. The treatment of the patients in our study began at other locations, which probably accounts for the lack of dominant disease activity, and this may be the cause for the lower than expected correlation levels between the RA diagnosis and level of ESR.

Some existing data has shown that CRP may reflect radiological damage in RA when it is used as the monitoring agent for disease activity instead of ESR. ${ }^{[8,9]}$ It has been reported that $56 \%$ of the patients diagnosed with RA had high CRP levels in the multicenter study by Pincus et al. ${ }^{[8]}$ In our study, among the patients who were referred to clinics with rheumatic complaints, $44.4 \%$ of the CRP values were found to be high, and a statistically significant positive correlation level was calculated between RA and the CRP results $(\Phi=0.289$, $\mathrm{p}<0.05)$. Although this result is close to the previous data in the literature and was found to be statistically significant, this rate had a lower than expected value. This could be due to RA patients whose disease activities were suppressed. 
In the beginning, RF was seen as a specific sign for $\mathrm{RA}$, but it was later put forth that RF was observed with positive rates of $60-80 \%$ among RA patients and that it was also found to be positive in a number of other diseases. ${ }^{[10,11]}$ In addition, it is known that RF positivity is an indication of poor prognosis and that long-term $\mathrm{RF}$ positivity is a risk factor for RA which stems from the patients with no complaints. ${ }^{[1]}$ In another study in our country, an RF positivity rate of $90 \%$ for RA patients was reported, which is similar to our study results. ${ }^{[12]}$ The RF was positive for $28.9 \%$ (77/270) of the patients in our study. This ratio was calculated as $89.6 \%(60 / 67)$ for the patients diagnosed with RA, and a statistically significant correlation level was observed between RF and RA $(\Phi=0.782, \mathrm{p}=0.000)$.

In a review that examined anti-CCP diagnostic values, it was reported that the sensitivity was $0.53 \pm 0.10$ and the specificity was $0.96 \pm 0.03 .{ }^{[3]}$ In the same study, it was also emphasized that second-generation antiCCP tests had higher sensitivity levels while the specificity values remained similar. ${ }^{[1]}$ Pincus et al. ${ }^{[8]}$ evaluated 37 different samples and found an anti-CCP sensitivity of 0.67 and a specificity of 0.95 for RA. In our study, the anti-CCP was positive for $21.5 \%$ of the patients who came to our PMR clinic with rheumatic complaints and findings. The anti-CCP positivity rate was $86.6 \%$ (58/67) for the patients diagnosed with RA, and there was a statistically significant correlation level calculated between RA and anti-CCP $(\Phi=0.920$, $\mathrm{p}=0.000$ ). Moreover, it was seen that the sensitivity, specificity, positive productivity, and accuracy ratios of anti-CCP were considerably higher than for the other investigated tests for RA.

Anti-CCP positivity in patients with non-defined arthritis, when examined independently from the other factors, has been suggested as an indicator for the development of RA. ${ }^{[13]}$ In another study, it was reported that anti-CCP autoantibodies had a stronger relationship with joint erosion but a weaker relationship with extra-articular symptoms when compared with $\mathrm{RF}^{[14]}$ It should be noted that although the diagnosis value of anti-CCP is high for early RA, it can also be positive for other rheumatic diseases as well as for $5 \%$ of the normal population. ${ }^{[8,15,16]}$ On the other hand, RA development has been reported in $25 \%$ of patients with early polyarthritis who originally tested negative for anti-CCP.

In conclusion, for patients with rheumatic complaints and findings, the diagnosis of RA should be specified after an evaluation of their history, clinical examinations, and laboratory and radiological findings. Although RF positivity may not be a single factor for specifying a diagnosis, it should be included among the evaluation criteria. Performing anti-CCP testing on a daily basis would be beneficial since it has high sensitivity and specificity values and it was the latest proposed classification criteria for the diagnosis of RA.

\section{Declaration of conflicting interests}

The authors declared no conflicts of interest with respect to the authorship and/or publication of this article.

\section{Funding}

The authors received no financial support for the research and/or authorship of this article.

\section{REFERENCES}

1. Goodyear CS, Tighe H, McInnes IB. Rheumatoid factors and other autoantibodies in rheumatoid arthritis. In: Firestein GS, Budd RC, Harris Jr ED, McInnes IB, Ruddy S, Sergent JS, editors. Kelley's textbook of rheumatology. 8th ed. Philadelphia: W.B. Saunders Company; 2008. [e-book]

2. Vasishta A. Diagnosing early-onset rheumatoid arthritis: the role of anti-CCP antibodies. Am Clin Lab 2002;21:34-6.

3. Zendman AJ, van Venrooij WJ, Pruijn GJ. Use and significance of anti-CCP autoantibodies in rheumatoid arthritis. Rheumatology (Oxford) 2006;45:20-5.

4. Aletaha D, Neogi T, Silman AJ, Funovits J, Felson DT, Bingham CO 3rd, et al. 2010 Rheumatoid arthritis classification criteria: an American College of Rheumatology/European League Against Rheumatism collaborative initiative. Arthritis Rheum 2010;62:2569-81. doi: 10.1002/art.27584.

5. Zhang Z, Gorman C, Clark JM, Cope AP. Rheumatoid arthritis: a disease of chronic, low-amplitude signals transduced through $\mathrm{T}$ cell antigen receptors? Wien Med Wochenschr 2006;156:2-10.

6. Pincus T, Yazici Y, Sokka T. Complexities in assessment of rheumatoid arthritis: absence of a single gold standard measure. Rheum Dis Clin North Am 2009;35:687-97. doi: 10.1016/j.rdc.2009.10.002.

7. Kushner I, Ballou SP. Acute-phase reactants and the concept of inflammation. In: Firestein GS, Budd RC, Harris Jr ED, McInnes IB, Ruddy S, Sergent JS, editors. Kelley's textbook of rheumatology. 8th ed. Philadelphia: W.B. Saunders Company; 2008. [e-book]

8. Pincus T, Sokka T. Laboratory tests to assess patients with rheumatoid arthritis: advantages and limitations. Rheum Dis Clin North Am 2009;35:731-4. doi: 10.1016/j. rdc.2009.10.007.

9. Ward MM. Clinical and laboratory measures. In: St. Clair EW, Pisetsky DS, Haynes BF, editors. Rheumatoid arthritis. 1st ed. Lippincott Williams \& Wilkins; 2004. [e-book] 
10. Bridges SL Jr, Davidson A. Rheumatoid factor. In: Koopman WJ, Moreland LW, editors. Arthritis \& Allied conditions. 15th ed. Lippincott Williams \& Wilkins; 2005. p. 1207-26.

11. De Angelis V, Meroni PL. Rheumatoid factors. In: Shoenfeld Y, Meroni PL, Gershwin ME, editors. Autoantibodies. 2nd ed. London: Elsewier; 2007. p. 1227-46.

12. Kobak S. Demographic, clinical, and serological features of Turkish patients with rheumatoid arthritis: evaluation of 165 patients. Clin Rheumatol 2011;30:843-7. doi: 10.1007/s10067-011-1678-5.

13. van Gaalen FA, Linn-Rasker SP, van Venrooij WJ, de Jong BA, Breedveld FC, Verweij CL, et al. Autoantibodies to cyclic citrullinated peptides predict progression to rheumatoid arthritis in patients with undifferentiated arthritis: a prospective cohort study. Arthritis Rheum 2004;50:709-15.
14. De Rycke L, Peene I, Hoffman IE, Kruithof E, Union A, Meheus L, et al. Rheumatoid factor and anticitrullinated protein antibodies in rheumatoid arthritis: diagnostic value, associations with radiological progression rate, and extra-articular manifestations. Ann Rheum Dis 2004;63:1587-93.

15. Symmons D, Mirjafari H. Classifi cation criteria. In: Hochberg MC, Silman AJ, Smolen JS, Weinblatt ME, Weisman MH, editors. Philadelphia: Rheumatoid arthritis. Mosby Elsevier; 2009. p. 1-13.

16. Singh U, Singh S, Singh NK, Verma PK, Singh S. Anticyclic citrullinated peptide autoantibodies in systemic lupus erythematosus. Rheumatol Int 2011;31:765-7. doi: 10.1007/ s00296-010-1374-9. 